\title{
Familiness as a form of value for wineries: A preliminary account
}

Jennifer Smith Maguire, University of Leicester

Paul Strickland, La Trobe University

Warwick Frost, La Trobe University.

Authors' final version (pre-proof) of:

J. Smith Maguire, P. Strickland \& W. Frost. (2013) Familiness as a Form of Value for

Wineries: A Preliminary Account. Journal of Wine Research. 24(2): 112-127.

\section{Abstract}

Based on a small, exploratory study of three family-owned wineries in Victoria, Australia, the paper examines how 'familiness' is constructed as a form of value. Drawing on work in cultural economy and economic sociology, we propose that familiness can be best understood as the outcome of a process of qualification that mediates between a winery's actual repertoire of properties and its cultural reception through the selective framing and legitimizing of family-related product properties as worthy points of attachment. There were five major themes around which the notion of family was clustered in the narratives of winery representatives and in winery marketing material: family as a key dimension of marketing strategy; the day-to-day involvement of family; the winery's family heritage; family as a symbolic quality; and the brand as family. Based on these findings, we argue that familiness may involve both indexical and iconic cues, that the material family is only one element in the construction of familiness as a form of value, and that familiness is legitimized as a point of attachment for consumers and employees through reference to authenticity, among other discourses.

\section{Introduction}

Family-owned and run wineries are the norm in the Australian wine industry (Deves, 1996; Frochot, 2000), mirroring the general pattern of family ownership within the tourism and hospitality sector (Getz et al., 2004: 1-2). Family involvement can serve as a distinctive form of competitive advantage for wineries (e.g. Misiura, 2006), and for customer serviceoriented businesses more generally (Cooper et al., 2005). While the peculiarities of family businesses may offer certain organizational advantages, the marketing appeal of the family firm must also be understood broadly, in the context of the current cultural climate. Amidst such concerns as food security and 'frankenfoods,' carbon footprints and the sustainability of global brands, and the loss of the authentic (e.g. Kniazeva, 2005; Gilmore and Pine, 2007; Sassatelli and Scott, 2001), provenance narratives focused on a brand's explicit link to a place or a person (and thus family) offer a way to re-embed and re-territorialize products, building consumer trust and loyalty (e.g. Carrigan and Buckley, 2008; Paxson, 2010). 
This paper offers a preliminary account of how family ownership and heritage are constructed as forms of value for family wineries. In doing so, we take a markedly different approach than that normally adopted within research on family businesses. Rather than examine how family involvement patterns the development, ownership and managerial dimensions of such wineries, we concern ourselves instead with how 'familiness' is constructed by winery brand representatives. Our discussion is based on a small, exploratory study of three wineries in north-eastern Victoria, Australia. Our analysis is informed by work within cultural economy and economic sociology (e.g. McFall, 2009) that understands product attributes (such as a winery's identity as a family winery) not as inherent properties, but as social accomplishments. Such a perspective is concerned with processes of qualification through which various actors attempt to singularize and objectify specific attributes of a product, and offer them as points of attachment to consumers. This cultural economy perspective on value formation has been used previously to consider the construction of provenance value for wine-such as when wine writers, sommeliers and retailers selectively highlight aspects of a wine's provenance (e.g. where it was made, by whom, when) in both their selection of wines to bring to market and their strategies in framing it as desirable for consumers (Smith Maguire, 2010, 2012). Here, we apply the framework to the case of the construction of familiness value for wineries.

Reflecting our distinctive theoretical approach and the exploratory nature of the project, our research problem is modest in scope, and interpretively framed: what are the dominant markers of familiness articulated by family winery brand representatives? Beyond this empirically-oriented objective, the paper is also intended as a distinctive contribution to the conceptualization of familiness as a specific form of provenance value. Given that such an approach is new to the area of wine research, the paper necessarily proceeds with a brief introduction to the concepts of familiness and value formation. This section is followed by an overview of the research design, before we offer our findings and suggest directions for further research.

\section{Familiness and Value Formation}

In this section, we offer a three-part introduction to the notion of familiness, from the points of view of conventional research on family firms, cultural economy conceptualizations of value formation, and related research on authenticity and provenance.

First: familiness is a concept that has emerged in the study of family firms (Pearson et al., 2008). Family businesses account for the majority of firms in most developed nations, and are prevalent in peripheral and emerging sectors such as tourism and hospitality (Getz et al., 2004). Furthermore, family firms are credited with a significant impact on entrepreneurial culture and economic growth (Carrigan and Buckley, 2008). And yet, within business, management and tourism studies, it is widely noted that family firms are an underresearched area (e.g. Chrisman et al., 2005).

To take the typical approach adopted in the study of family businesses, we would regard the family firm - the family winery-as the unit of analysis (e.g. Woodfield, 2010). However, such an approach is associated with several problems. One has to do with setting 
parameters: reviews of the literature find more than thirty working definitions of family firms employed in this area of research (e.g. Chua et al, 1999). In addition, as Carrigan and Buckley (2008: 657) point out, researchers often take the distinctiveness of family firms for granted, declaring that their dynamics offer advantages, without questioning how and in what ways (if at all) family firms differ from non-family firms. Furthermore, family firms are often conflated (by researchers and consumers) with small firms, which ignores the range of scales of family businesses, and ascribes competitive advantages - such as rapid response to customer needs - to the family basis of the firm, rather than its size and managerial structure (Carrigan and Buckley 2008: 658).

In light of these problems, there has been some shift in focus from family firms per se to 'familiness' (see Pearson et al., 2008 for a useful review). Habbershon and colleagues propose a model of 'distinctive familiness,' a form of competitive advantage that arises from the idiosyncratic combination of resources and capabilities of particular 'enterprising' families. Their model attempts to take into account interactions not only within such families, but also with the larger business entity, in a way that recognizes that family firms vary from the 'copreneurial couple, to the multigenerational owned and managed firm, to the family-controlled public company' (Habbershon et al., 2003: 463). Building on the concept yet taking a quite different tack, Carrigan and Buckley (2008) approach familiness from the point of view of consumers. They identify several dimensions in UK and Irish consumers' perceptions of family firms, including an association of family firms with greater levels of personal service, a positive valuation of their role within communities and local business networks, and confidence in their trustworthiness in business dealings and the authenticity and quality of their goods. Nevertheless, the 'familiness' that is perceived by consumers is treated as a fait accompli in their research. Overall, 'familiness' remains relatively unproblematized in the family firm literature, its particular sources and types still elided by the family itself (Chrisman et al., 2005). The family (or 'enterprising family') remains as a primordial (and thus unquestioned) fount of familiness.

At the heart of this paper, in contrast, is the assumption that familiness is a sociallyconstructed and conditional property. This brings us to our second point of introduction: familiness can be better understood as the outcome of the qualification of goods - here, the qualification of the family winery. Our discussion works from the perspective (associated with cultural economy, 'new' economic sociology, and anthropological approaches to the study of markets) that value is a contingent accomplishment, and the market is a lived social practice (Callon et al., 2002; McFall, 2009; Miller, 2008; Muniesa et al., 2007; Slater, 2002). Such an approach may be broadly understood as an 'analysis of the steps through which economic quantities and qualities are formed....[1]t is an attempt to identify the varied impulses and articulations through which value is formed, added and circulated' (Amin and Thrift, 2004: xiv-xv).

A cultural economy approach to value begins from the position that any object or cultural good has a repertoire of material and symbolic properties available for framing as the object's qualities. Various market actors intervene along the commodity chain, singling out particular properties from this repertoire of possibilities, disentangling them from their actual context, and attempting to objectify their singularity (e.g. through brand narratives in advertising and service interactions that focus on one particular material property such as 
speed, to the exclusion of all others); and framing singularized properties as points of attachment (e.g. framing that particular material property of speed as 'efficient' or 'exciting' to appeal to particular consumer desires or fears). A wide range of case studies have examined how those intervening market actors (or 'cultural intermediaries') draw on specific devices and dispositions in mediating between cultural goods and their reception, putting particular material and symbolic properties of goods into dialogue with particular discursive frames in order to construct the object as desirable, worthy and legitimate (see Smith Maguire and Matthews, 2010 for a review). The credibility of any such framing will also involve the evaluations of consumers: cultural intermediaries must make the singularized and objectified points of attachment intelligible to consumers (or other actors located along the commodity chain involved in the process of qualification and requalification), who will negotiate the relative fit between these points of attachment and their own motivations, desires and identities (McFall, 2009; Smith Maguire and Matthews, 2012).

Working from this position, we therefore suggest that 'family wineries' are contingent entities. A family-owned and run winery is not necessarily a 'family winery' - just as, more generally, the number of family firms (60 per cent in most developed countries; Carrigan and Buckley, 2008: 656) will outstrip the number of firms that explicitly position themselves in the marketplace via their familiness. The construction of familiness as a form of value for a specific winery will involve the selective singularization and objectification of particular elements from a winery's entire repertoire of material and symbolic properties, and their framing as worthy points of attachment. The actual involvement of family memberscentral in the conventional approach to family firms-is but one aspect of a winery's development, organization, identity and so forth that may be utilized in the qualification of wineries and formation of familiness (as we demonstrate via our findings).

Third: further insight as to the formation of familiness may be drawn from research on how authenticity and provenance shape wine industries and consumer markets more generally. Authenticity refers to a 'recognition of difference' or distance (Fine, 2003: 155)-articulated, for example, as an opposition to the market (and all the instrumental calculation and mass production that implies) or as an opposition to otherwise inescapable change, as in fidelity in style to an 'original.' Socio-cultural scholars have highlighted authenticity as a key driver in the contemporary marketplace and theme in consumer culture (e.g. Gilmore and Pine, 2007; Peterson, 2005; Zukin, 2009). A dominant theme in this area of research is that authenticity is not an intrinsic property residing in the object or experience, but a situated accomplishment, 'an assessment made by a particular evaluator in a particular context' (Grayson and Martinec, 2004: 299). Studies of such diverse goods as automobiles (Leigh et al., 2006), clothing (Botterill, 2007), beer and whisky (Beverland et al., 2008; Spracklen, 2011), and gourmet food journalism (Johnston and Baumann, 2007) have identified a common set of markers associated with authenticity, including economic disinterestedness and anti-commercialism, the natural and the rural, heritage and tradition, and the local and hand-crafted rather than the mass-produced and industrialized.

This 'list' of common markers is best understood as a set of potential material and symbolic properties that may be discursively framed as authentic-properties that relate strongly with an object's context of production, or its provenance. The provenance of a product 
refers to where it was produced, by whom, how and when, and includes any number of moments from creation to consumption (Smith Maguire, 2012). Provenance is one way in which authenticity is offered as a point of attachment: of an object's entire repertoire of material and symbolic properties, provenance-related properties are common as concretizing anchors for authenticity markers, particularly for rural and agricultural goods such as food and wine (e.g. Beverland and Luxton, 2005; Johnston and Baumann, 2007; Paxson, 2010).

The significance of provenance in generating value within the wine market is well recognized. Properties that provide tangible, credible geographic and biographic specificity to a wine are significant in strategies to gain competitive advantage in a crowded marketplace, establish consumer interest and loyalty, and premiumize wine's market position. Provenance via geographic specificity is illustrated in the Australian case with the move towards regionality, which 'is high on the agenda for many wine producing countries, for without it, a wine region must compete on price, not easy to do given the excess of supply over demand' (Easingwood et al., 2011: 30). A New World response to Old World terroir, regionality is employed as a strategy to gain credibility within the super-premium wine market, as illustrated by the Australian Wine and Brandy Corporation - the industry's major trade body-which has adopted several provenance and regionality-related marketing initiatives in recent years, including Regional Heroes ('wines that are from somewhere rather than wines from anywhere') and the ' $A+$ ' campaign that promotes the specificity of the country's different regions. Our concern is with the construction of provenance via both biographic and geographic specificity, as is illustrated by the 'Australia's First Families of Wine' (AFFW) promotional campaign. Launched in 2009, AFFW explicitly draws on the family ownership, heritage and place specificity of 12 Australian producers (who together represent ' 1200 years of winemaking experience') in an effort to premiumize the perception of Australian wine in major export markets. ${ }^{1}$

\section{Methods}

Our exploratory study focuses on three wineries in north-eastern Victoria (two in the Rutherglen area, and one in King Valley). Data collection took place in 2011 and consisted of field notes made at visits to the wineries; examination of promotional material (principally, winery websites); and semi-structured interviews (in person, lasting 30-60 minutes) with a representative from each winery. Interview transcripts were approached from an interpretive stance, with the responses treated as instances of the construction of the familiness of the brand. A thematic analysis of the transcripts was approached both deductively and inductively (Fereday and Muir-Cochrane, 2006). The discussion in this paper focuses primarily on the transcript data deductively coded for 'family' and related terms (e.g. 'generation'), which was then inductively coded to identify the specific themes around which references to family were clustered. As in related research on the construction of authenticity at Scottish whisky distilleries (Spracklen, 2011, following LeGreco and Tracy, 2009), we 'trace' the articulation of familiness along these different levels of text and talk, in order to identify the most common markers or anchors of familiness as they occur through the brand narrative, as accomplished by the brand representative, in the physical site, and in the promotional material. 
All three wineries were selected because they are family-owned: Campbells Winery, Brown Brothers Winery and Scion Winery. ${ }^{2}$ The definitional difficulties associated with the variation in family firms, highlighted in the preceding section, are reflected in our limited sample. Campbells and Brown Brothers are multi-generational wineries, established in 1870 and 1885 respectively. They remain family-owned, are founding members of the AFFW marketing initiative, and are among the biggest operators for the region and for familyowned Australian winemakers. For Campbells, production is mainly in the Rutherglen area. Brown Brothers has vineyards in several regions, with its only cellar door at the original vineyard in King Valley. In contrast, Scion is a small, mother-and-son winery in operation since 2002 in Rutherglen, with only eight acres of vineyards.

Furthermore, respondents varied in their family connectedness to the wineries: the Campbells and Rutherglen representatives are non-family members (working for their winery for seven and over 20 years, respectively), while the Scion representative is the son, who joined the winery about five years ago. Our three respondents offer a useful reminder to not take familiness for granted: a family member from a new, family-run winery, and two non-family members of multi-generational family-owned and managed wineries.

North-Eastern Victoria is a well-established, small wine region, 250-300 kilometres northeast of Melbourne. It is divided into five sub-regions that include Rutherglen and King Valley. Rutherglen, on the plains of the Murray River, has a hot climate and is renowned for its red wines, particularly Shiraz and Durif. The King Valley is cooler and in recent years has diversified into a wide range of new Mediterranean varieties, such as Sangiovese. Even as recently as the late 1980s, North-Eastern Victoria was the largest wine region in the state (Victorian Tourism Commission, 1986); today, however, it accounts for only five per cent of the state's cellar doors (Tourism Victoria, 2008). In 2008, the region had 33 wineries with cellar doors open to the public, of which 14 were in Rutherglen (Tourism Victoria, 2008). Nearly all of these are small to medium family-owned enterprises, with a mix of claims to local heritage: a third-11 wineries, 8 of which are in Rutherglen-date from before World War One, whereas nearly all the wineries in the King Valley have opened since the 1990s (Tourism Victoria, 2008). Thus, the wineries discussed here are from a region in which heritage-for the region, families or varietals -is already a well-defined and promoted property.

To be clear: this research is exploratory. Our analysis is based on a small number of respondent views; we do not aim to generalize findings to all family wineries (or, for that matter, to all family firms). Rather, our emphasis is on using the data to help develop a theoretically-informed conceptualization of familiness. Furthermore, our research is focused entirely on the experiences and practices of those involved in representing the brand; we are not examining consumers' attitudes. While past research highlights that consumers may associate notions of distinction, community, trust and authenticity with family firms (e.g. Carrigan and Buckley, 2008), and that consumers are active in evaluating authenticity claims (Grayson and Martinec, 2004), we are mindful that the self-presentation of brands (here, articulated through the narratives of the brand representatives, the physical sites of the wineries and in their promotional material) is not dependent on consumer perceptions. As Paxson (2010) observes of artisanal cheesemakers, whether or not consumers 'buy into' the brand identity espoused by producers may be irrelevant, provided that producers are able to 
sell their wares and make a living.

\section{Findings}

The theme of family was prevalent in the interviews. For example, all respondents were asked as an initial warm-up question to briefly describe their winery, and all mentioned family. Over the course of the interviews, other descriptors and attributes were also offered - of these, family was by far the most frequently recurring term across the interviews. This was not surprising, given that all three wineries were approached because of their family ownership, and respondents had been informed that the research concerned family involvement in wineries. However, the theme of family occurred not only across the three interviews, but also across responses to questions that ranged from respondents' views of their winery's brand identity, its place within the region, and its marketing strategy, to respondents' career paths and current responsibilities. In total, 'family' was mentioned 16 times by the Scion representative, 30 times by the Campbells representative, and over 60 times by the Brown Brothers representative.

From an inductive analysis of these more than 100 instances, there emerged five major themes around which the notion of family was clustered in the brand representatives' accounts: family as a key dimension of marketing strategy; day-to-day family involvement; family heritage; family as a symbolic quality; and the brand as family. As an introduction to how these themes were articulated by the respondents, let us first review their presence in the wineries' promotional material, and specifically their websites. The wineries differ in the degree to which they position themselves as family wineries on their websites, with Scion being the least focused on familiness. The family connection is absent from Scion's homepage: the strapline reads 'estate grown boutique wines;' the brand statement reads 'Scion is a dynamic and creative wine business. We craft fruit from traditional Rutherglen varieties into innovative, unique wines.' The family connection is instead made through 'Our Story', the first of nine links in the homepage's main navigation menu, which provides information on the mother and son's relation to one of the founders of the Rutherglen wine industry in the late 1800 s. A further link then provides biographical information on the pair.

In contrast, familiness is to the fore on the Campbells and Brown Brothers websites. Campbells is the most explicitly positioned via familiness, in terms of brand message ('Our wines spring from the unique qualities of the Rutherglen Wine Region, five generations of knowledge and a dedication to innovation'), imagery (a photo of fourth and fifth generation family members among wine barrels is one of three main images that cycle at the top of the homepage), and navigational menu (with 'Our History' as one of four links from the 'About Us' link on the homepage navigational menu). On the Brown Brothers homepage, familiness is highlighted in the brand message ('Steeped in tradition and inspired by innovation, every bottle comes from our family to yours') and reinforced through 'Our Family,' the second of seven links on the page's main navigation menu, as well as by a small image of the family for the 'news and events' link, below the main navigation menu. Brown Brothers' reference to the consumer's family is echoed at Scion (where the ardent consumer is invited to become a 'Scionista') and at Campbells (one of three family member quotations that cycle in the left hand column of the homepage reads: 'A family winery is not just the wine in the bottle it's 
the soil under your fingernails its [sic] storms and spring sunshine, tears and laughter and customers who become family friends').

Thus, the five themes identified in the transcripts are also present in the websites: an intersection of text and talk in our analysis of the discourse of familiness. There are references to: first, the 'family' - as term, idea and image-in the marketing material; second, the actual involvement of family members; third, the historical involvement of the family; fourth, particular symbolic connotations of the family/family winery (e.g. dedication, tradition, innovation); and fifth, the brand including others (e.g. consumers) in the family. Below, we consider how each of these themes is articulated in the interviews.

\section{Family as marketing strategy}

'Family' was cited by all three respondents as important to their winery's market position, and to the region's tourism marketing. This was certainly to be expected from both the Campbells and Brown Brothers representatives, given the foundational role both wineries have played in the family-oriented AFFW programme, but was also explicitly acknowledged by the Scion representative. For example:

I guess [the AFFW] is done to alleviate the perception, especially in Europe, [...of] Australia as a country of mass produced, homogenised wines made in factories that are churned out without their passion or soul. [...] Sure, there's a lot of big companies [in AFFW] and Browns are a big company. But being a family owned company, that gives us ability - an edge, because we are more about the passion of wine. The passion about people is very important and that gives that edge. (Brown Brothers)

We are probably the most prominent in the region in pushing the family aspect of the business, and that's [...] a card that we play with all of our sales and marketing activities, so all of our events and our dinners are all about joining the family. [...W]e talk about being a fifth generation family wine-making concern which we use to differentiate ourselves from the majority of the 2900 other wineries in the country. [later in the interview]

AFFW is all about [...] reminding people about the heart and soul of the Australian industry and where it has come from, and it has come from multi-generational family wineries with long-term aspirations rather than sort of short-term profiteering aspirations. (Campbells)

I mean it's one of Rutherglen's, I think, breadwinning marketing pitches, is generational wine making. They talk about third, fourth, fifth generation wine making. There are not many areas in Australia that can offer that to a punter. [...I]t's a clever way to give the area an identity and point of difference. (Scion)

For all three respondents, family assumes a taken-for-granted role in marketing (be it at the national level-AFFW-or regional place-branding initiatives within north eastern Victoria). This theme undoubtedly reflects the respondents' specific market location (i.e. they are located in a region that explicitly markets itself through family heritage, and are all awareif not explicitly involved in-the AFFW initiative). Indeed, as the Campbell representative remarked, 'family permeates everything that you do' in Rutherglen. 
However, while this theme stems in part from our choice of respondents, we propose that it also reflects the more general myth of familiness in the marketplace. That is, the idea that family offers a de facto competitive advantage ('an edge;' a 'point of difference'), which is associated with a particular ethos (passionate; not driven by short-term financial gain), has not only been normalized in research on family firms (Carrigan and Buckley, 2008), but also by family firms themselves. Our respondents thus identify family not simply as a marketing strategy, but also, at the same time, associate it with a particular orientation to the market that emphasizes long-term and personal commitment over short-term calculations of the economic bottom line; a finding to which we return below with regard to the symbolic connotations of family.

\section{Family involvement}

All three brand representatives highlighted the current material involvement of family in the day-to-day operation of the wineries. In the case of Scion, day-to-day family involvement is fundamental to the winery's operation:

Basically, it's a very small winery. It's family run. Mum and I do 99 per cent of the work. It's hands-on, from growing [...] our own fruit. [...] We're producing everything on site and very much start to finish the process from setting up the vines at the start of their growing cycle through to selling that bottle at the end of the day, whether it's a restaurant or on premise. [...] It's also very hands-on in the way we sell the wine and talk about it and present it in cellar door. Cellar door is our main focus with sales, so we try and get the whole story and the whole picture across the line there and it seems to work quite well. [...] We are a quality focused operation that we like to think is very honest and down-to-earth about what we do. (Scion)

Family involvement at Scion is a function of the scale of the operation-small enough to allow two family members to accomplish the majority of the commodity chain from viticulture to retail-but it is also constructed as the external referent or guarantor for their brand identity as 'quality focused..., honest and down-to-earth.'

In the case of the much larger scale wineries, however, the actual involvement of family members (raised by both respondents) was intertwined with the involvement of non-family members. For example:

Quite often we get people who come to the [cellar door] and say, 'Are you really Brown Brothers? Are you really a family owned company?' It's not like Dick Smith. ${ }^{3}$ They use his photo but he's got nothing to do with Dick Smith any more. (Brown Brothers)

Coming to Rutherglen I think more often than not [visitors] would expect to be able to talk with someone from the family. It's not always easy because we're a busy place but, yeah, certainly at events and what have you, people don't come to hear me talk. They come to hear directly from the family [...] That's quite an important aspect for us [given] the amount of events that we do over a year, so just from a logistics point of view we sort of need to break the family up sometimes: 'All right, you go to this and you come along to this.' But, yeah, I think it's fairly evident people want to hear directly from family. It's a very big factor. (Campbells)

That is, both wineries are sufficiently large operations that their day-to-day operation rests primarily on non-family members. Nevertheless, both representatives went into detail of 
the specific family members involved and their roles, and-as mentioned above-both wineries feature photos of the active family members on their website.

What we see here is an example of 'strategic decoupling' (Beverland and Luxton, 2005) between a brand's material operations and its brand image, with the involvement of some family members singularized and framed as representative of the brand. This practice is not particular to our sample. In the Champagne industry, which has been characterized historically by family firms and more recently by a process of consolidation (Charters, 2012), the involvement of present-day family members and (as a segue to our next theme) family heritage are strategically and selectively highlighted, in contrast to the realities of the ownership and organizational structure, as, for example, at Krug and Veuve Clicquot, both owned by multinational luxury goods conglomerate LVMH.

\section{Family heritage}

The historical dimension of family involvement received much more emphasis than current involvement, in the interviews and on the websites. The frame of reference for family heritage was regional, ${ }^{4}$ and featured in the narratives of all three representatives. For example:

[T] he vineyard which we selected here and planted on was originally the Bobbie Burns gold lead. So Rutherglen, in that sort of 1850 period [...] the discovery of gold, and that soon brought about 30,000 people to the district. (Campbells)

[W]e've got connection with the Morris family, which is one of the founding generational families with viticulture in the area. Geoff Morris, who is one of the founding members of viticulture in Rutherglen [...] I'm a great, great, great grandson [...] That's why we established our vineyard here. That plays into our hands sometimes with cellar door discussions. (Scion)

Ever since John Francis Brown made our first wines here in 1889 [...] he was the first generation [...T] here's never been a break, it's been continuous. Most of those 120 years, a lot of them were I guess being quite a small family owned company, nowhere as big as now. (Brown Brothers)

That heritage-for the winery family, and for the region-is then reflected in and made durable (Latour, 1991) through marketing material (e.g. on the websites, as discussed above) and through the design of the winery itself. For example, at Scion:

Where the winery is now, there was a vineyard going back to the ' 30 s before it burnt down. [...] We've used a lot of red gum and all that stuff, which is quintessentially Australian and very Rutherglen, being by the Murray River, a lot of Murray red gum. Similarly, Campbells' cellar door-a building from the 1970s-blends with the original cellar from the 1880s and features century-old barrels, providing a physical reiteration of the winery's claim to family heritage. In addition, both Campbells' and Brown Brothers' websites contain detailed historical information on the wineries' generational milestones and notable family members.

\section{Family as symbolic quality}

Besides references to the material involvement-present and past-of families in the wineries, all three representatives' narratives associated family with a range of symbolic 
qualities, some of which have already been raised, including long-term commitment, passion, dedication and innovation. We identify two broad connotations of family within this theme. The first set of associations links family with authenticity, in (explicit or implicit) contradistinction to corporate brands (as above, in the reference to Dick Smith). For example:

So it's really that family that-the authenticity, the genuine down-to-earth aspects that-you know, loyal and trustworthy. All of these things [...] are quite tactile things that people can buy into. That's what family is all about, isn't it? [later in the interview] I suppose the beauty of 140, 141 years of family winemaking is that you don't need to contrive a history or to create stories. They're all there to use. (Campbells)

It's basically about being around for a long time to be able to survive in the long term [...T] he belief is you can't run a family owned company to make profit all the time. It can't be tied up with having shareholders where you've got to make money all the time. It's not about quick fixes. (Brown Brothers)

It needs to have purpose or meaning. It seems a means to an end if it doesn't. I think when something has been thought out it can have more purpose and more relevance. I think with a business, when it's not just a nine to five, it's a seven to 12 , it needs that meaning, because it's what you live.

[later in the interview]

We don't just pour wines and try and sell them in that very one-two sort of punch, which I think you see quite regularly when you tour for wine. (Scion)

In these examples and others, the representatives frame their wineries as authentic by attributing a set of qualities to the family nature of the winery: the family heritage is cited as proof of genuineness (compared with the 'contrived' stories of corporate brands), and economic disinterestedness (as opposed to the profit-driven ethos of non-family firms). The privileging of qualities such as genuineness and a privileging of passion over profit are not exclusive to family firms, as research on authenticity suggests (e.g. Johnston and Baumann, 2007). For our respondents, familiness served as conceptual shorthand for a range of associations for respondents, which reframed (or obscured) the economic interestedness of the family firm in terms of authenticity, passion and commitment.

The second set of associations links the family winery (rather than family per se) with two seemingly conflicting qualities of tradition and innovation:

Rutherglen's [point of difference] is the historical, the heritage elements and, of course, family. I would probably put family at the front of that list because the historical and the heritage aspects can, at times, work against you as well when you're competing against modern, new and interesting wineries. (Campbells)

Whilst we've got family history, we've also got an ability to innovate and generate new styles, new ideas and really push the boundaries of what's grown here. [...] So we kind of use the old to give us some credibility, but with our new energy, try and go outside the square, because I think whilst tradition can be a wonderful thing, it's also a huge Achilles heel. (Scion) 
[1]t's a family owned company that's innovative and listens what the consumers want and then try to deliver on that, through innovation [...] I guess we have got a tradition of being innovative, so that is our tradition I guess. (Brown Brothers)

Co-present in brand narratives that highlight heritage and tradition as material properties are references to symbolic properties that mediate that heritage, framing it as something complementary, rather than antithetical, to innovation and change. This may reflect the wineries' market location in a global sense: just as regionality may be regarded as a New World response to Old World terroir, the emphasis on the marriage of tradition and innovation may work as a point of differentiation from an Old World framed as static and unchanging.

While tradition and innovation may appear to be irreconcilable attributes, familiness resolves any apparent contradiction by framing both as hallmarks of the family: an entity rooted by its heritage, which continues to grow and change with successive generations. Similarly in the case of associations with authenticity: familiness resolves any apparent contradiction between the genuineness of the winery and the economic realities of making a winery viable. In this, we see one of Miller's 'uses of value': familiness acts as a 'bridge between what otherwise might be incommensurate regimes' of meaning (Miller, 2008: 1127). Like myths, which offer a way of making sense of paradoxes and resolving contradictions (Levi-Strauss, 1963), familiness creates value by mediating between oppositions: authenticity and the market, tradition and innovation.

\section{Brand as family}

The final theme in the findings concerns the symbolic property of family as inclusive, involving affective (if not kinship) bonds. This is articulated in the transcripts in terms of the brand as family, both for customers, as well as for (non-family) employees. Considering the consumer dimension first, we note examples across the interview transcripts and webpage material that position the consumer as a family friend or family member. For example, the Campbells webpage describes their wine club: 'Our Cellar Club helps us keep in touch with the many friends we have made over the years.' This is elaborated upon by the Campbell's representative:

Of course [the wine club is] all about people forming connections with the winery and, by proxy, the family. [...W]ithout giving it the marketing spin, we consider our cellar club members to be part of the extended family and, really, they make a bond with Campbells and a bond with the family that you can't generate through a retail outlet or via a website. It's a very tangible thing.

The Scion homepage offers visitors the chance to 'Read Scionista Feedback,' framing customers as members of a collective, and the respondent's account of the cellar door experience frames customer relations in convivial terms:

Sometimes people are here for three hours. They don't want to go [...] We offer a really relaxed experience and that helps people to return. That's how we see the way we trade. It's very successful. We have huge return visitation. We have very loyal customers and we enjoy talking to them about wine. So everyone's happy. (Scion) These examples suggest that familiness is associated in part with a non-instrumental relationship with consumers - which reinforces the symbolic associations of family with genuineness and non-instrumentality, as in the preceding theme. This dimension of familiness is ascribed by the respondents to the family nature of the winery. However, 
attention to a brand's affective relationship with consumers is a trend to be found more generally in the contemporary marketplace (Arvidsson, 2006), and the potential to generate value (or, 'co-create' value) through personalized experiences and interactive service work is not the exclusive domain of family wineries, but reflects strategies adopted across a range of types of service-oriented, interactive wine marketing settings (Hollebeek and Brodie, 2009).

On the second front (one largely neglected in existing discussions of family brands) is the familial connection that can develop between employer and employee. For example:

I suppose when I'm at cellar door, [I hear] 'Are you with the family?' I say, 'I'm with the family.' (Campbells)

In the Campbells interview, this was the only instance of explicit self-framing as part of the family; however, the theme is implicit throughout in language and the choice of personal pronouns, as above: 'we consider our cellar club members...' (emphasis added).

However, the family connection between brand and employee was a recurrent theme for the Brown Brothers representative, occurring over five separate instances in the transcript. For example:

People often ask me on the counter-that's where I spend most of my time-'Are you a Brown?' I say, 'I'm not technically a Brown but I'm sort of a Brown.' (Brown Brothers)

This may partly reflect his lengthy tenure of more than 20 years at the winery, but it also relates to the material practices of the winery that attempt to make durable (Latour, 1991) the relationship between employees and family firm. For example, employees of twenty years or more have their names placed on barrels in the cellar as a concretization of their connection with the company. Similarly, the company holds a dinner each year to celebrate employees of ten years or more:

The last one had 150 people attend [...] You take into account some of those people have been here for 30 years as well. There's many hundreds of years of experience there. That's where it's up to us to keep that feeling going, be there in place of the family members if you like.

Thus, for the Brown Brothers representative at least, the strategic value of employees adopting, and feeling adopted by, the brand is explicit, and is the measure of good (effective) employees:

It's like we want people to think as they're coming in to - not the family home, but coming to talk to people who have a passion for the company and having that sort of family feel. That's the thing that we teach all the staff is, it's not about selling [...] It's about promoting the family. That's the paramount reason that we're here.

In this way, the symbolic associations of family (e.g. authenticity) works in concert with the idea of the brand as family, and the material property of the actual family involvement in the brand. Understandably, then, this theme did not feature in the Scion transcript where the size of the operation may make such a dimension of familiness irrelevant.

\section{Discussion}

Drawing on the findings from our exploratory study of three family-owned wineries, we suggest that familiness be disentangled from the family, in order to better grasp how it is 
constructed as a form of value in the contemporary marketplace. Examining common themes across instances of both talk and text, we identified five common ways in which the family features in the brand narratives for our wineries, with reference to: winery marketing strategy, family involvement in winery operation, history of family involvement in winery operation, symbolic properties associated with family, and family-like relationships with customers and employees. From these findings, we take away three final points regarding the conceptualization of familiness, which suggest directions for further research.

First, our research demonstrates that familiness may involve both indexical and iconic cues. On the one hand, the day-to-day involvement of family members is singularized in the respondents' narratives and the website content, and offered as an indexical point of attachment: 'a factual and spatio-temporal link' (Grayson and Martinec, 2004: 298) between the consumer and the family. On the other hand, considerably more emphasis fell on iconic points of attachment that offered a symbolic link to the family, including images of the family and its lineage, and family proxies in the form of winery staff. There appears to bein our sample at least-an inverse relationship between material and symbolic family involvement: the more diluted the family's role in the day-to-day operations, the greater the representational emphasis on the family in promotional material.

Our findings, albeit preliminary, also reinforce the significance of frontline service workers in representing and embodying brands (Witz et al., 2003). Past research has already suggested the significance of winery staff in creating a personalized experience and emotional bond with cellar door visitors (e.g. Nowak and Newton, 2006); our data suggests that it may not be the case that small wineries necessarily have an advantage in this (Fountain et al, 2008). Rather, brands-small or large-are at an advantage if they can effectively inculcate and leverage familiness amongst their employees, as was the case most notably for the Brown representative. Credible family proxies add value to the firm by creating more points of attachment for consumers looking for authenticity. Through their service interactions, these proxies make familiness tangible for consumers, serving as sincere spokespeople for the marketing strategy and narratives about family and brand heritage, multiplying the involvement of (proxy) family members and providing concrete evidence of the brand's familiness ethos. Given the potential significance of such proxies, further research is needed on how 'family' (as a material or symbolic property) may serve as a point of attachment for employees, be it for family-owned brands or not (as in the case of UK retailer John Lewis; see Miller, 2008).

Second, in assessing how family wineries frame themselves and make sense of the family in their brand narratives, physical sites and promotional material, we have demonstrated that the material family is only one element in the construction of familiness as a form of value. Some of these properties, like present-day family involvement and family heritage, can be understood as a sub-set of a brand's provenance elements: aspects of the 'where, how, when and who' of the context of production that relate specifically to family. Others have more to do with wineries' interactive service networks: relationships with repeat customers (or even successive generations of customers), or with their brand representatives. Othersespecially the symbolic connotations and affective bonds associated with 'family'-derive as much from wider cultural discourses (such as that of authenticity) as from concrete, material anchors. This research progresses our understanding of familiness, not by 
attempting to exhaustively catalogue the material and symbolic sources of familiness but by demonstrating that there is more than the family per se at play in framing a winery as a 'family winery.'

Third, just as our research suggests the need to look beyond just the family in the construction of familiness, we would also propose looking beyond authenticity. Through our review and application of insights from economic sociology and cultural economy, we argue that familiness can be best understood as the outcome of a process of qualification that mediates between a winery's actual repertoire of properties and its cultural reception through the selective framing and legitimizing of family-related product properties - both material (e.g. the kinship unit) and symbolic (e.g. a set of ideals). Our small sample of wineries demonstrates how the discourse of authenticity is used to frame such properties. However, the cultural reception of any good will be mediated by a range of discourses, of which authenticity is but one. We would anticipate, based on research on consumer attitudes to ethical goods (e.g. Beagan et al., 2010), that there are other legitimizing frameworks that are-or could be-employed in the construction of familiness, including discourses of social justice, security, collective identity and distinction.

Thus, this research helps to make the case for a cultural economic approach to familiness as an accomplished value, and underlines the need for further, theoretically-informed and empirically-grounded research. Wineries-family-owned or otherwise-are more likely to do a better job articulating familiness if they can grasp the range of potential material and symbolic anchors, and frames of legitimacy that are available to them. From our limited sample, we identified a range of devices for constructing and concretizing familiness as a form of value. These included the use of images and quotations from present-day family members, references to the accomplishments and context of ancestors, espousal of kinship feelings, passion, long-term perspectives and so forth. Such anchors are selectively singularized and placed in mutually reinforcing dialogue through the promotional content of websites, design of the winery, product narratives on labels, brand narratives delivered in service interactions, rituals around training staff and acknowledging long-term employees, and various other devices. Through such a complex and multi-layered process of qualification, a winery is thereby constructed as a family winery.

In closing, we suggest that firms are more likely to generate competitive advantage via familiness if they understand its value as both a point of attachment (for consumers as well as employees) and as a device for mediating between other brand values or product properties that are otherwise difficult to reconcile (Miller, 2008). Thus, our research highlights the potential value of familiness not simply for the family winery, but for any firm attempting to strategically bridge the commercial and the non-instrumental, the industrial and the artisanal, the traditional and the new.

\section{References}

AMIN, A. and THRIFT, N.J., eds. (2004) The Blackwell Cultural Economy Reader, Oxford: Blackwell.

ARVIDSSON, A. (2006) Brands: Meaning and Value in Media Culture, London: Routledge. 
BEAGAN, B.L., RISTOVSKI-SLIJEPCEVIC, S. and CHAPMAN, G.E. (2010) 'People are just becoming more conscious of how everything's connected': 'Ethical' food consumption in two regions of Canada, Sociology, 44 (4), 751-69.

BEVERLAND, M.B., LINDGREEN, A. and VINK, M.W. (2008) Projecting authenticity through advertising: Consumer judgments of advertisers' claims, Journal of Advertising, 37 (1), 5-15.

BEVERLAND, M. and LUXTON, S. (2005) Managing integrated marketing communication through strategic decoupling, Journal of Advertising, 34 (4), 103-16.

BOTTERILL, J. (2007) Cowboys, outlaws and artists: The rhetoric of authenticity in contemporary jeans and sneaker advertisements, Journal of Consumer Culture, 7 (1), 105-25.

CALLON, M., MÉADEL, C. and RABEHARISOA, V. (2002) The economy of qualities, Economy and Society, 31 (2), 194-217.

CARRIGAN, M. and BUCKLEY, J. (2008) 'What's so special about family business?': An exploratory study of UK and Irish consumer experiences of family businesses, International Journal of Consumer Studies, 32, 656-66.

CHARTERS, S. (2012) The organization of champagne: A historical and structural introduction, in: CHARTERS, S. (ed) The Business of Champagne: A Delicate Balance, London: Routledge, 3-14.

CHRISMAN, J.J., CHUA, J.H., and STEIER, L.P. (2005) Sources and consequences of distinctive familiness: An introduction, Entrepreneurship Theory and Practice, 29 (3), 237-47.

CHUA, J.H., CHRISMAN, J.J. and SHARMA, P. (1999) Defining the family business by behaviour, Entrepreneurship Theory and Practice, 23 (4), 19-37.

COOPER, M.J., UPTON, N. and SEAMAN, S. (2005) Customer relationship management: a comparative analysis of family and non-family business practices, Journal of Small Business Management, 43 (3), 242-56.

DEVES, M., ed. (1996) The Australian and New Zealand Wine Industry Directory, Prospect East: Wine Titles.

EASINGWOOD, C., LOCKSHIN, L. and SPAWTON, A. (2011) The drivers of wine regionality, Journal of Wine Research, 22 (1), 19-33.

FEREDAY, J. and MUIR-COCHRANE, E. (2006) Demonstrating rigor using thematic analysis: A hybrid approach of inductive and deductive coding and theme development, International Journal of Qualitative Methods, 5 (1), 1-11.

FOUNTAIN, J., FISH, N. and CHARTERS, S. (2008) Making a connection: tasting rooms and brand loyalty, International Journal of Wine Business Research, 20 (1), 8-21.

FROCHOT, I. (2000) Wine tourism in France: A paradox?, in: HALL, C.M., SHARPLES, L., CAMBOURNE, B. and MACIONIS, B (eds) Wine Tourism Around the World.

Development, Management and Markets, Oxford: Elsevier Butterworth-Heinemann, 67-80.

GILMORE, J.H. and PINE, B.J., II. (2007) Authenticity: What Consumers Really Want, Boston: Harvard Business School Press.

GETZ, D., CARLSEN, J. and MORRISON, A. (2004) The Family Business in Tourism and Hospitality, Wallingford: CABI.

GRAYSON, K. and MARTINEC, R. (2004) Consumer perceptions of iconicity and indexicality and their influence on assessments of authentic market offerings, Journal of Consumer Research, 31 (2), 296-312. 
HABBERSHON, T.G., WILLIAMS, M.L. and MACMILLAN, I.C. (2003) A unified systems perspective of family firm performance, Journal of Business Venturing, 18 (4), 451-65.

HOLLEBEEK, L.D. and BRODIE, R.J. (2009) Wine service marketing, value co-creation and involvement: research issues, International Journal of Wine Business Research, 21 (4), 339-53.

JOHNSTON, J. and BAUMANN, S. (2007) Democracy versus distinction: A study of omnivorousness in gourmet food writing, American Journal of Sociology, 113 (1), 165204.

KNIAZEVA, M. (2005) Marketing 'frankenfood': Appealing to hearts or minds?, Journal Of Food Products Marketing, 11 (4), 21-39.

LATOUR, B (1991) Technology is society made durable, in: LAW, J. (ed) A Sociology of Monsters: Essays on Power, Technology, and Domination, London: Routledge, 103-31.

LEGRECO, M. and TRACY, S. (2009) Discourse tracing as qualitative practice, Qualitative Inquiry, 15 (9), 1516-43.

LEIGH, T.W., PETERS, C. and SHELTON, J. (2006) The consumer quest for authenticity: The multiplicity of meaning within the MG subculture of consumption, Journal of the Academy of Marketing Science, 34 (4), 481-93.

LEVI-STRAUSS, C. (1963). Structural Anthropology, New York: Basic Books.

MCFALL, L. (2009) Devices and desires: How useful is the 'new' new economic sociology for understanding market attachment?, Sociology Compass, 3 (2), 267-82.

MILLER, D. (2008) The uses of value, Geoforum, 39, 1122-32.

MISIURA, S. (2006) Heritage Marketing, Burlington: Elsevier.

MUNIESA, F., MILLO, Y. and CALLON, M. (2007) An introduction to market devices, The Sociological Review, 55 (Issue Supplement S2), 1-12.

NOWAK, L.I. and NEWTON, S.K. (2006) Using the tasting room experience to create loyal customers, International Journal of Wine Marketing, 18 (3), 157-65.

PAXSON, H. (2010) Locating value in artisan cheese: Reverse engineering terroir for NewWorld landscapes, American Anthropologist, 112 (3), 444-57.

PEARSON, A.W; CARR, J.C; and SHAW, J.C. (2008) Toward a theory of familiness: A social capital perspective, Entrepreneurship Theory and Practice, 32 (6), 949-69.

PETERSON, R.A. (2005) In search of authenticity, Journal of Management Studies, 42 (5), 1083-98.

SASSATELLI, R. and SCOTT, A. (2001) Novel food, new markets and trust regimes: Responses to the erosion of consumers' confidence in Austria, Italy and the UK, European Societies, 3 (2), 213-44.

SLATER, D. (2002) Capturing markets from the economists, in: DU GAY, P. and PRYKE, M. (eds) Cultural Economy: Cultural Analysis and Commercial Life, London: Sage, 59-77.

SMITH MAGUIRE, J. (2010) Provenance and the liminality of production and consumption: The case of wine promoters. Marketing Theory, 10 (3), 269-82.

SMITH MAGUIRE, J. (2012) Provenance as a filtering and framing device in the qualification of wine, Consumption, Markets and Culture, iFirst Article: 1-24.

SMITH MAGUIRE, J. and MATTHEWS, J. (2010) Cultural intermediaries and the media, Sociology Compass, 4 (7), 405-16.

SMITH MAGUIRE, J. and MATTHEWS, J. (2012) Are we all cultural intermediaries now?, European Journal of Cultural Studies, 15 (5), 551-62.

SPRACKLEN, K. (2011) Dreaming of drams: Authenticity in Scottish whisky tourism as an expression of unresolved Habermasian rationalities, Leisure Studies, 30 (1), 99-116. 
TOURISM VICTORIA. (2008) The Wine Regions of Victoria, Melbourne: Tourism Victoria.

VICTORIAN TOURISM COMMISSION. (1986) Vintage Victoria: Your Wine and Food Guide, Melbourne: Victorian Tourism Commission.

WITZ, A., WARHURST, C. and NICKSON, D. (2003) The labour of aesthetics and the aesthetics of organisation, Organization, 10 (1), 33-54.

WOODFIELD, P.J. (2010) Intergenerational entrepreneurship in family businesses: A wine industry perspective, International Academy of Wine Business Research Conference, February, Auckland, NZ.

ZUKIN, S. ( 2009) Naked City: The Death and Life of Authentic Urban Places, New York: Oxford University Press.

\section{Acknowledgements}

The authors wish to acknowledge La Trobe University's Faculty of Business, Economics and Law for funding to undertake data collection and transcription. In addition, the first author would like to acknowledge La Trobe University's Graduate School of Management for a visiting fellowship that facilitated such collaboration, and the University of Leicester, for a period of study leave that facilitated the process of writing.

\section{Notes}

${ }^{1}$ Information on these various promotional campaigns can be found online. For example, Regional Heroes ('wines that are from somewhere rather than wines from anywhere') is one of four main 'personalities' in the 'Wine Australia' brand message (see, for example, http://www.wineaustralia.com); the 'At' campaign, launched June 2010, promotes the specificity of regional origin and the personal narratives of winemakers (see http://www.australiaplus.com); and the 'Australia's First Families of Wine' initiative, launched in 2009, highlights the 12 most prominent and longstanding winemaking families in Australia and their 'over 1200 years of winemaking experience' (see http://www.australiasfirstfamiliesofwine.com.au).

${ }^{2}$ All of the respondents gave permission to be identified by name and by winery. For sake of clarity and brevity, we identify respondents by winery name alone.

3 'Dick Smith' is an Australian retailer of electrical goods; the chain was founded by Dick Smith, an Australian entrepreneur. When the business was later sold to Woolworths, the chain retained the Dick Smith title-implying a personal, family connection where one no longer exists.

${ }^{4}$ Linked to a gold rush in the 1850s that brought emigrants and money to the region, winemaking started with English and Scottish settlers in the 1860s. Wine Australia (http://www.wineaustralia.com/uk/) provides summaries of the various regions' histories. 